\title{
The effect of enzyme treatment of cooked barley and supplementation of piglet diets on the digestibility of barley and piglet performance
}

\author{
J. INBORR ${ }^{1}$, M. NÄSI ${ }^{2}$ and K. SUOMI ${ }^{3}$
}

I Finnish Sugar Co. Ltd., Finnfeeds Ltd., Forum House, Brighton Road, Redhill, Surrey RHI 6YS, England

2 University of Helsinki, Department of Animal Husbandry, Viikki, 07100 Helsinki, Finland

${ }^{3}$ Agricultural Research Centre, Swine Research Station, SF-05840 Hyvinkää, Finland

\footnotetext{
Abstract. A digestibility trial, designed as a 5*5 Latin square, with growing pigs was conducted to investigate the effect of cooking and enzyme treatment of barley on digestibility and nitrogen utilization. In addition, two piglet performance trials were conducted to investigate the effect of hydrothermal processing of barley and soybean meal and enzyme supplementation of piglet feeds on performance and health status.

Five pigs, averaging $40 \mathrm{~kg} \mathrm{LW}$, were fitted with $\mathrm{T}$-shaped cannulas in the terminal ileum and fed the experimental diets for five consequtive 12-day experimental periods. Chromic oxide was used as marker.

Cooking of barley significantly improved the apparent faecal digestibility (AD) of DM, $\mathrm{OM}, \mathrm{CP}$ and $\mathrm{EE}(\mathrm{p}<0.5)$. AD of ash, $\mathrm{CF}, \mathrm{CCH}$ and $\mathrm{NDF}$ was also improved by cooking, but not significantly. Treating cooked barley with enzymes decreased AD values for most nutrients to a level slightly higher than that of ground barley. Nitrogen retention and biological value of protein, however, was markedly improved by cooking and to a greater extent by the enzyme treatment.

Ileal digestibility results were confusing, mainly due to problems in getting representative samples and recovering the marker. Consequently, these results are not reported.

The energy content of cooked barley was calculated to be $1.17 \mathrm{FU} / \mathrm{kg} \mathrm{DM}(15.32 \mathrm{MJ} \mathrm{ME} / \mathrm{kg}$ DM) and that of ground barley 1.09 FU/ $\mathrm{kg}$ DM (14.27 MJ ME/ $\mathrm{kg} \mathrm{DM})$, the values of the enzyme treated barleys being intermediate.

In trial 1, a total of thirty-six litters were allotted to three treatments of twelve replicates. Piglets were fed the experimental diets ad. lib. from two to eight weeks and were weaned at five weeks of age. Treatments were: 1 . basal diet containing untreated barley and SBM, 2 . basal diet, containing cooked barley and extruded SBM and 3. diet 2 with added enzymes.

Final weights and live weight gains on treatment 2 and 3 were significantly $(p<0.05)$ inferior to treatment 1 . There were no differences in feed intake and utilization between treatments. Health status of piglets on treatment 2 and 3 was inferior to that of treatment 1 . No piglets were medicated due to diarrhoea.

In trial, 2, forty-eight early-weaned piglets were allotted to two treatments of four replicates. Piglets had free access to the experimental diets during the 19-day experimental period.
} 
Diets were formulated to have the same composition. In treatment 2, however, an enzyme mixture was added at a five times higher inclusion rate than in treatment $1(0.5 \mathrm{vs} .0 .1 \%$, respectively). Piglets on treatment 2 gained $8 \%$ faster weight than those on treatment 1 . Feed intake was slightly higher on treatment 2 , but feed conversion ratio was $7 \%$ lower. Due to high variation within treatments the differences between treatments were not significant $(p>0.05)$. There were no differences in health status between treatments.

Index words: barley, cooking, enzyme treatment, enzyme supplementation, digestibility, piglet performance

\section{Introduction}

The purpose of hydrothermal processing of feed raw materials is to rupture the cell wall matrix and modify the chemical structure of the constituents in order to render them more susceptible to enzyme degradation in the small intestine, thus improving the digestibility and utilization of the nutrients. Furthermore, heat treatment of soybeans, beans and peas has been shown to decrease the content of antinutritional factors such as trypsin inhibitors, lectins and tannins leading to an increased feeding value (Huisman and VAN Der Poel, 1987).

Starch is the main constituent in cereals and hydrothermal processing causes changes in the structure of the starch granules, which increase their degradability (FERnANDEs et al., 1975; Lawrence, 1972; 1973 a). Carbohydrates present in the gut for a long time may constitute substrates for microbial proliferation, resulting in the formation of useful or noxious substances.

Non-starch polysaccharides (NSP) and lignin, a mixture of compounds known as fibre, are poorly digested by the pig. The amount and type of dietary fibre influence the digestibility of nutrients. The higher the content of fibrous material in the diet, the greater also the proportion of dietary and endogenous fat, starch etc. being transferred to the large intestine probably due to a reduced transit time allowing less time for enzymatic digestion in the small intestine (JuST, 1983).

Gel-forming polysaccharides such as the beta-glucans together with pentosans are the main components in barley endosperm cell walls. Like barley, oats also contains relatively high amounts of beta-glucans, whereas wheat only contains small amounts (ÅMAN, 1987). Soluble beta-glucans form viscous solutions and in the intestine and tend to gel the contents. These gels restrict diffusion of products of digestion and make it difficult for the nutrients to reach the absorptive surface (Krogdahl, 1987). Both water and more effectively beta-glucanase treatment of barley have been shown to reduce extract viscosity and decrease the molecular weight of soluble beta-glucans and pentosans (Hesselman, 1983).

The effect of hydrothermal processing on the digestibility and feeding value of cereals has been elucidated in many experiments. The results from processing e.g. wheat and barley have not been consistently positive (DANIELSEN, 1986, Lawrence, 1973 b, KNeAle, 1972). An explanation for this could be a decreased availability of the amino acids due to heating . In fact, heat processing of cereals has been shown to decrease nitrogen solubility (PApasolomontos and Wilkinson, 1976) and to reduce the availability of e.g. lysine (HuRRELl and CARPENTER, 1981).

Alternatives to the conventional processes are of great interest, while it seems that they are connected with some risks regarding the effect on protein quality and production efficacy. In addition, these processes require 
substantial amounts of energy, which increases the costs of the processed raw materials.

The objective of this report was to elucidate the effect of enzyme treatment of cooked barley on ileal and faecal digestibility and nitrogen balance in pigs. In addition, two performance trials were conducted with piglets to investigate the effect of hydrothermal processing of barley and SBM and enzyme supplementation of piglet diets.

\section{Materials and methods}

\section{Digestibility trial}

This trial was carried out at the Department of Animal Husbandry of the University of Helsinki.

\section{Animals and management}

Five crossbred $\left(\mathrm{L}^{*} \mathrm{Y}\right)$ castrates, averaging 40 $\mathrm{kg} \mathrm{LW}$, were surgically fitted with metallic T-shaped cannulas in the terminal ileum, approximately $15 \mathrm{~cm}$ anterior the ileocaecal junction, according to the technique described by JoNSSON (1985). Five days after surgery, the pigs were transferred to metabolism cages, where they were housed during the trial. The design of the cages permitted separate collection of urine and faeces.

Equal amounts of feed, mixed with water (ratio 1: 1), were offered three times a day at 0700,1500 and $2100 \mathrm{~h}$. The average feed intake was 1600, 1800, 2000, 2200 and $2400 \mathrm{~g}$ per day during the five consequtive experimental periods, respectively. Additional water was offered ad. lib. after each feeding, and consumption was recorded during the collection periods.

Each experimental period consisted of a 6-day standardisation, a 4-day faecal collection and a 2-day ileal collection period. Faeces were collected for 96 hours starting at 0830 h on day 6 of each experimental period. During days 11 and 12, samples of ileal digesta
$(50 \mathrm{ml})$ were collected eight times a day with two hour intervals, starting at $0700 \mathrm{~h}$. Each sample was frozen immediately after collecting. Prior to analysis, samples were thawed and mixed.

\section{Design and treatments}

The experiment was a 5*5 Latin Square design. Five diets, containing differently treated barley, casein, barley starch (Bst), barley protein (Bpr) and chromic oxide as an indigestible marker, were offered to each pig during the 60-day experiment. Barley was giound (B) and cooked $(\mathrm{BC})$ in diets 1 and 2, respectively. In diet 3, cooked barley was treated with alfa-amylase (Novo Industries, Denmark) $(\mathrm{BC}+\mathrm{A})$, in diet 4 with alfa-amylase and glucoamylase (Finnish Sugar Co. Ltd.) $(\mathrm{BC}+\mathrm{AG})$ and in diet 5 with alfa-amylase and cellulase (Finnish Sugar Co. Ltd.) (BC + AC).

The diets were formulated to contain $15 \%$ CP. Due to the low CP content of BC, $2.5 \%$ Bpr was added to diet 2 instead of Bst, which was added to the other diets at the same inclusion level. In addition to the experimental diets, pigs were given $40 \mathrm{~g}$ mineral mix (Fosfori-Hertta) daily and vitamins once a week. Chromic oxide was added at a level of $0.25 \%$ in the diets. The composition of the experimental diets is shown in table 1.

\section{Preparation of the raw materials}

Ground barley (B) was steam heated at 90$100^{\circ} \mathrm{C}$ for 60 seconds to a moisture content of approximately $30 \%$ followed by toasting in an oil-heated drum, for about 30 seconds, resulting in a gelatinization of $50-60 \%$ of the starch (BC). The enzyme preparations were sprayed onto the cooked barley during mixing and allowed to act for about $30 \mathrm{~min}$. prior to drying $(\mathrm{BC}+\mathrm{A}, \mathrm{BC}+\mathrm{AG}$ and $\mathrm{BC}+$ AC). The effect of the treatments on the release of reducing sugars is shown in table 3 .

The soybean meal used in diets 2 and 3 of trial 1 was extruded by a single-screw extruder. 
Table 1. Composition of the experimental diets, $\%$.

\begin{tabular}{|c|c|c|c|c|c|}
\hline Treatment & 1 & 2 & 3 & 4 & 5 \\
\hline Barley (B) & 91.75 & - & - & - & - \\
\hline Barley, cooked (BC) & - & 91.75 & - & - & - \\
\hline$B C+A$ & - & - & 91.75 & - & - \\
\hline $\mathrm{BC}+\mathrm{AG}$ & - & - & - & 91.75 & - \\
\hline $\mathrm{BC}+\mathrm{AC}$ & - & - & - & - & 91.75 \\
\hline Casein & 5.50 & 5.50 & 5.50 & 5.50 & 5.50 \\
\hline Bst & 2.50 & - & 2.50 & 2.50 & 2.50 \\
\hline Bpr & - & 2.50 & - & - & - \\
\hline Chromic oxide & 0.25 & 0.25 & 0.25 & 0.25 & 0.25 \\
\hline
\end{tabular}

The exit temperature was approximately $130^{\circ} \mathrm{C}$.

\section{Analytical methods}

Dry matter, ash, crude protein, ether extract and crude fibre were determined according to standard methods. NDF and ADF were assayed according to GoERING and VAN SOEST (1970). Reducing sugars were determined with the dinitrosalisylic acid (DNS) method (MrLLER, 1959) using glucose as a standard. Chromic oxide was analysed by AAS.

Amino acids were assayed at the National Laboratory of Agriculture with an automatic amino acid analyser (Chromakon 400) following hydrolysis and separation by ion-exchange chromatography, and available lysine was determined by difference following pretreatment of the samples with flourodinitrobenzene (PAO et al., 1963). Energy values were calculated according to Finnish feed tables by using the digestibility coefficients obtained from the digestibility trial (SALo et al., 1982).

\section{Statistical analysis}

Analysis of variance for Latin square experiments was used for digestibility measurements.

\section{Performance trials}

\section{Experimentals}

Trial 1. This trial was carried out at the Swine Research Station in Hyvinkää. A total of thirty-six new-born litters of L-, Y- and $\mathrm{L}^{*} \mathrm{Y}$ crossbred sows, comprising 7 or more piglets, were allotted to three treatments of twelve replicates each. Litters from sisters or closely related sows were allocated to different treatments, which included litters from both gilts and multiparous sows.

Table 3. Chemical composition of the raw materials, $\mathrm{g} / \mathrm{kg} \mathrm{DM}$.

\begin{tabular}{lrrrrrrrr}
\hline Raw material & B & BC & BC + A & BC + AG & BC + AC & Casein & Bpr & Bst \\
\hline Dry matter & 945 & 948 & 951 & 955 & 947 & 956 & 965 & 939 \\
Ash & 26 & 25 & 26 & 26 & 26 & 82 & 42 & 2 \\
Crude protein & 129 & 122 & 126 & 128 & 127 & 882 & 376 & 7 \\
Ether extract & 33 & 34 & 38 & 40 & 40 & 10 & 62 & - \\
Crude fibre & 64 & 55 & 66 & 70 & 72 & - & - & 520 \\
N-free extracts & 748 & 746 & 744 & 736 & 735 & 76 & - & - \\
NDF & 202 & 173 & 200 & 198 & 202 & - & - & - \\
ADF & 55 & 42 & 60 & 59 & 62 & - & & \\
Reducing sugars* & & 6 & 135 & 201 & 128 & & & \\
Glucose* & & $<1$ & 11 & 115 & 18 & & & \\
\hline
\end{tabular}

* determined in $\mathrm{BC}, \mathrm{BC}+\mathrm{A}, \mathrm{BC}+\mathrm{AG}$ and $\mathrm{BC}+\mathrm{AC}$. 
Table 2. Composition of the experimental diets, $\mathrm{g} / \mathrm{kg}$.

\begin{tabular}{|c|c|c|c|c|c|}
\hline \multirow[t]{2}{*}{ Diet } & \multicolumn{3}{|c|}{ Trial 1} & \multicolumn{2}{|c|}{ Trial 2} \\
\hline & 1 & 2 & 3 & 1 & 2 \\
\hline Barley & 457 & - & - & - & - \\
\hline Barley, cooked & - & 445 & 444 & - & - \\
\hline Barley, hydrotherm. & - & - & - & 421 & 417 \\
\hline Dehulled oats, steamed & 300 & 300 & 300 & 370 & 370 \\
\hline Soybean meal (SBM) & 88 & - & - & - & - \\
\hline SBM, extruded & - & 100 & 100 & - & - \\
\hline SBM, hydrotherm. & - & - & - & 75 & 75 \\
\hline Fish meal & 60 & 60 & 60 & 60 & 60 \\
\hline Fat blend & 5 & 5 & 5 & - & - \\
\hline Skim milk powder & 25 & 25 & 25 & - & - \\
\hline Whey powder & - & - & - & 20 & 20 \\
\hline Glucose & 35 & 35 & 35 & 20 & 20 \\
\hline Dicalcium phosphate & 19 & 19 & 19 & 19 & 19 \\
\hline Calcium carbonate & 3 & 3 & 3 & 5 & 5 \\
\hline Sodium chloride & 1.5 & 1.5 & 1.5 & 2.0 & 2.0 \\
\hline L-lysine $\mathrm{HCl}$ & 1.8 & 1.6 & 1.6 & 2.1 & 2.1 \\
\hline DL-methionine & - & 0.1 & 0.1 & - & - \\
\hline L-threonine & 1.0 & 0.8 & 0.8 & 0.7 & 0.7 \\
\hline Premix* & 4.0 & 4.0 & 4.0 & 4.0 & 4.0 \\
\hline Carbadox, ppm & 50 & 50 & 50 & 50 & 50 \\
\hline Enzyme-premix & - & - & 1.0 & 1.0 & 5.0 \\
\hline $\mathrm{ME}, \mathrm{MJ} / \mathrm{kg}$, calculated & 14.1 & 14.1 & 14.1 & 14.0 & 14.0 \\
\hline $\mathrm{FU} / \mathrm{kg}$, calculated & 1.05 & 1.05 & 1.05 & 1.05 & 1.05 \\
\hline
\end{tabular}

* vitamins and trace elements according to requirements.

The piglets were accustomed to the experimental diets from one week of age and had free access to the diets from two weeks to the end of the trial at seven weeks of age. The feeds were provided in self-feeders. Water was provided through nipples and available continuously.

The piglets were weaned at 5 weeks by removing the sow from the farrowing pen, in which piglets stayed until the end of the trial.

The diets were formulated to have similar chemical composition. In diet 1 , barley and SBM were untreated. In diet 2 and 3, all barley and SBM were replaced with cooked barley and extruded SBM, respectively. Because the raw materials were processed at a different feed mill than the one in which the feeds were compounded, different batches were used for diet 2 and 3 than for diet 1 . These unfortunate circumstances resulted in a lower CP levels in the first diet. To get diet 3 , an enzyme mixture containing alfa-amylase, cellulase and protease was added to diet 2. Crude protein, lysine and energy contents of the diets were calculated to be $185 \mathrm{~g} / \mathrm{kg}, 11.5 \mathrm{~g} / \mathrm{kg}$ and 1.05 FU/kg (14.1 MJ ME/kg, respectively. The composition of the diets is shown in table 2 .

Piglets were individually weighed at birth, at weaning and at the end of the trial. Feed consumption, mortalities and the occurrence and severity of diarrhoea were recorded (scale of severity in table 10). Scouring piglets were treated with antibiotics.

Trial 2. In this trial, carried out at Munkkila Experimental Station in Paimio, fortyeight crossbred $\left(\mathrm{L}^{*} \mathrm{Y}\right)$ piglets, weaned at an age of five weeks and averaging $13 \mathrm{~kg}$ in live weight, were allotted to two treatments of twenty-four animals, each group comprising 12 gilts and 12 castrates. Piglets on each treatment were allocated to four replicates into pens with six piglets, on sex and live weight basis. There were two pens with gilts and two pens with castrates on each treatment. Dur- 
ing the 19-day experimental period, piglets were fed ad. lib. from self-feeders, having access to one feeder per pen. Water was provided through nipples (one per pen) and was available for the animals continuously.

All piglets were penned in the same row of an automatically air-conditioned enclosed section with a row of pens on each side of the central passage. One third of the $1.6^{*} 2.4 \mathrm{~m}$ concrete floor of the pens was slatted. Pens were partitioned by a $60 \mathrm{~cm}$ high solid steel wall and an additional $30 \mathrm{~cm}$ steel-pipe construction. During the first week, the air temperature was $25^{\circ} \mathrm{C}$ and decreased $2^{\circ} \mathrm{C}$ weekly.

The diets were formulated to contain different levels of enzyme activities by supplementing different amounts of an enzyme-premix containing beta-glucanase (Finnish Sugar Co. Ltd.), alpha-amylase and protease (Novo Industries). The basal diet contained hydrothermally treated cereals and SBM, fish meal, whey powder and glucose. The inclusion levels of the enzyme-premix was $0.1 \%$ and $0.5 \%$ in diets 1 and 2 , respectively. The lower level represents the inclusion rates used in some commercial feeds. Unfortunately, due to limited facilities it was not possible to include a negative control in this trial. The composition of the diets is shown in table 2. The feeds were compounded at the Sampola feed mill, pelleted and then crumbled.

The piglets were individually weighed at the beginning and at the end of the trial. The feeders were refilled once a day according to feed consumption and the amounts were recorded.

During the trial, the health status of the piglets was monitored and in case of diarrhoea, affected piglets were treated with an antibiotic (Orimysin).

\section{Analytical methods}

Feed and amino acid analyses were carried out according to the methods described above. Enzyme activities of the feeds were measured at the Finnish Sugar Research Centre. Alfaamylase activity was determined by using the Phadebas Amylase Test (Pharmacia). Beta- glucanase activity was determined by measuring the rate of production of reducing sugars (MILLER, 1959) when beta-glucan was used as a substrate at $\mathrm{pH} 5.0$ and $30^{\circ} \mathrm{C}$. Protease activity of the feeds was determined according to the method by Matsubara et al. (1958) using casein as a substrate.

The energy content of the diets was calculated according to referred values of the Finnish feed tables (SAlo, et al. 1982).

\section{Statistical analysis}

Analysis of variance (one way classification) was used for the performance measurements in trial 1. The diarrhoea index values were compared by the $\mathrm{Chi}^{2}$-test and mortality values of treatments 2 and 3 were compared to the values of treatment 1 one at a time by using the unpaired Student's T-test. Mean values of the measurements of trial 2 were compared by unpaired Student's T-test.

\section{Results and discussion}

\section{Digestibility trial}

\section{Chemical composition of the diets}

The chemical composition and amino acid content of the raw materials are shown in tables 3 and 4, respectively. Cooking of barley resulted in a small decrease in the crude protein content. Similar results have been reported when barley was either micronized (Fernandes et al., 1975; Lawrence, 1973 a) or heated (KNEALE, 1972). Ether extract and crude fibre content of the enzyme-treated barleys were somewhat higher than in BC. Also the NDF and ADF content of the enzyme-treated barleys were higher than in BC. The increased levels of NDF may contain some Maillard products, which had escaped the hydrolyzation of the analysis (VAN SOEST, 1982).

The effect of enzyme-treatment on the release of reducing sugars and glucose is shown in table 3. Barley contains about $0.1 \%$ of glu- 
Table 4. Amino acid contents of the raw materials, $\mathrm{g} / 16 \mathrm{~g} \mathrm{~N}$.

\begin{tabular}{|c|c|c|c|c|c|c|c|}
\hline Raw material & B & $\mathrm{BC}$ & $\mathrm{BC}+\mathrm{A}$ & $\mathrm{BC}+\mathrm{AG}$ & $\mathrm{BC}+\mathrm{AC}$ & casein & Bpr \\
\hline Ala & 4.2 & 4.2 & 4.2 & 4.2 & 4.3 & 3.2 & 3.9 \\
\hline Arg & 5.3 & 5.3 & 5.1 & 5.3 & 5.1 & 3.9 & 4.0 \\
\hline Asp & 5.6 & 6.3 & 6.3 & 6.5 & 6.3 & 7.7 & 5.0 \\
\hline Cys & 2.7 & 2.7 & 2.5 & 2.6 & 2.6 & 0.6 & 2.2 \\
\hline Glu & 23.1 & 23.1 & 22.4 & 21.5 & 20.3 & 22.0 & 21.3 \\
\hline Gly & 4.2 & 4.2 & 4.3 & 4.2 & 4.3 & 1.9 & 3.7 \\
\hline $\mathrm{His}$ & 2.4 & 2.4 & 2.2 & 2.2 & 2.1 & 3.0 & 2.2 \\
\hline Ile & 3.7 & 3.7 & 3.5 & 3.5 & 3.4 & 5.5 & 3.4 \\
\hline Leu & 7.4 & 7.3 & 7.1 & 7.1 & 7.0 & 10.5 & 7.1 \\
\hline Lys & 3.9 & 3.9 & 3.6 & 3.5 & 3.6 & 8.0 & 3.2 \\
\hline Met & 2.2 & 2.0 & 1.8 & 1.8 & 1.6 & 2.9 & 1.8 \\
\hline Phe & 5.2 & 5.4 & 5.2 & 5.2 & 4.9 & 5.6 & 5.8 \\
\hline Pro & 11.0 & 10.9 & 10.3 & 9.5 & 9.1 & 11.5 & 12.2 \\
\hline Ser & 4.4 & 4.5 & 4.4 & 4.4 & 4.3 & 5.9 & 4.3 \\
\hline Thr & 3.8 & 3.7 & 3.6 & 3.6 & 3.4 & 4.5 & 3.4 \\
\hline Tyr & 3.2 & 4.5 & 3.2 & 3.3 & 3.4 & 6.2 & 3.6 \\
\hline Val & 5.1 & 5.1 & 5.0 & 4.9 & 4.7 & 6.6 & 4.7 \\
\hline Available lys & 3.4 & 3.3 & 3.0 & 2.8 & 3.0 & 7.1 & 3.1 \\
\hline
\end{tabular}

cose in DM (Åman and Hesselman, 1984) and according to the results cooking of barley did not have any effect on the glucose content. Alfa-amylase in combination with glucoamylase yielded the highest amounts of sugars.

The content of first limiting amino acids (lysine, threonine, methionine and cystein) was lower in the enzyme-treated barleys than in untreated and cooked barley. Also the amount of available lysine was smaller in the enzymetreated barleys. This indicates that some browning reactions (Maillard-reactions) have occurred. These reactions between the carbonyl group of a reducing sugar and a free amino group of an amino acid or protein reduce the availability of susceptible amino acids, especially lysine (Hurrell and CARPENTER, 1981). The marked increase in the concentration of reducing sugars in the enzyme treated barleys seems to have increased the incidence of these reactions.

\section{Apparent digestibility}

Due to problems in obtaining representative samples of the ileal digesta and in recovering the chromic oxide, the results of the ileal di- gestibility of the diets were too confusing to be interpretable. Therefore, these results will not be presented in this paper.

The apparent digestibility (AD) coefficients of the diets, determined by direct assay, are presented in table 5 . The AD of ground barley was similar to that reported by NÄsı (1984), with the exception of AD of $\mathrm{CF}$, which was higher in the present trial.

Micronization of barley increases the digestibility of DM, nitrogen and gross energy (Fernandes et al., 1975; Lawrence, 1973 a). In this present trial, cooking of barley significantly $(\mathrm{p}<0.05)$ increased the AD of DM, ash, OM, CP and EE. Also the AD of CF was improved, but not significantly. AD of DM $(\mathrm{p}<0.05)$ and $\mathrm{OM}(\mathrm{p}<0.01)$ in $\mathrm{BC}$ was significantly higher than in $\mathrm{B}, \mathrm{BC}+\mathrm{A}$ and $\mathrm{BC}+$ $\mathrm{AG}$ and approximately the same as in $\mathrm{BC}+$ AC.

Enzyme treatment of $\mathrm{BC}$ decreased the AD of most nutrients to the same level as in ground barley. Only the AD of EE was higher in the enzyme treated barleys than in B $(\mathrm{p}<0.05)$. The AD coefficients of $\mathrm{BC}+\mathrm{AC}$ were the highest among the enzyme-treated barleys. There were no significant differences in $\mathrm{AD}$ of $\mathrm{CP}$ between $\mathrm{B}$ and the enzyme- 
Table 5. Apparent digestibility of the diets, $\%$ (direct assay).

\begin{tabular}{|c|c|c|c|c|c|c|}
\hline Treatment & 1 & 2 & 3 & 4 & 5 & SEM \\
\hline DM & $80.6^{b}$ & $85.4^{a}$ & $80.6^{b}$ & $80.7^{b}$ & $81.9^{\mathrm{ab}}$ & 0.681 \\
\hline Ash & 38.5 & 48.0 & 41.4 & 39.8 & 45.2 & 2.632 \\
\hline OM & $82.6^{\text {bd }}$ & $87.1^{\text {ac }}$ & $82.5^{\text {bd }}$ & $82.7^{\text {bd }}$ & $83.7^{\text {bed }}$ & 0.592 \\
\hline $\mathrm{CP}$ & $78.0^{b}$ & $84.6^{a}$ & $82.9^{\mathrm{ab}}$ & $82.4^{\mathrm{ab}}$ & $84.1^{\mathrm{ab}}$ & 1.138 \\
\hline $\mathrm{EE}$ & $39.8^{d}$ & $59.2^{c}$ & $60.9^{c}$ & $59.9^{\circ}$ & $65.7^{\mathrm{c}}$ & 2.376 \\
\hline $\mathrm{CF}$ & 19.9 & 31.0 & 7.4 & 19.5 & 17.6 & 3.675 \\
\hline NFE & $90.6^{\mathrm{ab}}$ & $92.6^{a}$ & $89.3^{\mathrm{b}}$ & $89.5^{\mathrm{b}}$ & $90.3^{\mathrm{ab}}$ & 0.450 \\
\hline $\mathrm{CCH}$ & $85.1^{\text {abcd }}$ & $88.5^{\text {ac }}$ & $83.2^{\text {bd }}$ & $83.6^{\text {bcd }}$ & $84.3^{\text {bed }}$ & 0.646 \\
\hline NDF & $44.1^{\text {abod }}$ & $53.9^{a c}$ & $32.9^{\text {bd }}$ & $37.4^{\text {bed }}$ & $40.3^{\text {abcd }}$ & 2.6 \\
\hline ADF & 3.7 & 18.1 & -5.7 & 3.3 & 9.1 & 4.198 \\
\hline
\end{tabular}

a, b $(p<0.05) ;{ }^{c, d}(p<0.01)$

treated barleys. The AD of $\mathrm{NFE}$ and $\mathrm{CCH}$ in $\mathrm{BC}+\mathrm{A}$ and $\mathrm{BC}+\mathrm{AG}$ were significantly lower than in $\mathrm{BC}(\mathrm{p}<0.05)$. This may be a consequence of the browning reactions that occurred, resulting in poorly digestible complexes of sugars and amino acids.

The AD of $\mathrm{OM}$ and $\mathrm{CCH}$ was significantly lower in $\mathrm{BC}+\mathrm{AC}$ than in $\mathrm{BC}$. $\mathrm{OM}$ and $\mathrm{CCH}$ include crude fibre. Treating cooked barley with enzymes markedly decreased the $\mathrm{AD}$ of $\mathrm{CF}$, which consequently also was seen as a reduced $\mathrm{AD}$ of $\mathrm{OM}$ and $\mathrm{CCH}$. The low $\mathrm{AD}$ coefficients of $\mathrm{CF}$ and the detergent fibre fractions of the enzyme treated barleys are probably a result of the action of the enzymes. Treating BC with enzymes yielded reducing sugars mainly from starch, but to some extent from some fiber fractions leaving more insoluble fractions intact. The residual fibres are thus even less digestible.

In young pigs, beta-glucanase supplementation of barley has improved performance and the digestibility of energy (Тномке et al., 1980) and crude protein (МАRKSTRöm et al., 1985). In a digestibility trial with pigs from 30 to $50 \mathrm{~kg}$ Lw Graham et al. (1986) did not obtain any significant improvement of the digestibility when a barley-based diet was supplemented with beta-glucanase. The apparent ileal digestibility of beta-glucan was found to be $68 \%$ in the unsupplemented and $72.3 \%$ in the supplemented diet $(p>0.05)$. These values corresponds well to the ones of 76$82.2 \%$ reported by Weltzien and Aherne
(1986) working with somewhat heavier pigs. THACKER et al. (1988) reported improvement in the digestibility of dry matter, crude protein and digestible energy of beta-glucanase supplemented hulless barley in pigs weighing $40 \mathrm{~kg}$. However, these improvements in the digestibility were not reflected in significant improvements in the performance of the pigs. In performance trials, enzyme supplementation of barley based diets have improved the feeding value of the diets for pigs (COLLIER and Hardy, 1986; Newman, 1983). In the present trial, cooking markedly increased the digestibility of barley leaving less potential for improvements by the enzyme treatments.

The $\mathrm{N}$-balance of the treatments is shown in table 6. Nitrogen intake and absorption was highest on treatment 2 and lowest on treatment 1 , resulting in the highest apparent digestibility of $\mathrm{N}$ on treatment 2 with slightly lower values for the enzyme treatments. Urine nitrogen excretion, however, was highest on treatment 2 and lowest on treatment 3 , resulting in the highest $\mathrm{N}$ retention for this latter treatment. The amount of nitrogen retained, calculated as per cent of both $\mathrm{N}$ intake and absorption, was higher on all enzyme treatments than on treatment 1 and 2. Consequently, biological value of the nitrogen was improved by the enzyme treatments. Due to large variation within treatments, none of the parameters was significantly different.

ZEBROWSKA (1973) showed that nitrogen absorbed from the large intestine was excreted 
in the urine, and did not contribute to the protein synthesis of the pig. JUST (1982) calculated the energy excretion into the urine to be $30.6 \mathrm{~kJ} / \mathrm{g}$ nitrogen (included in urea and other nitrogenous substances).

It is a well known fact that the higher the nitrogen intake the higher the AD of the nitrogen. The unabsorbed nitrogen arriving in the large intestine will, depending on the amount of fermentable substrates available for the microbes, either be incorporated in to the microbial tissue or deaminated and absorbed as $\mathrm{NH}_{4}$ and subsequently excreted in the urine as urea. The decreased $\mathrm{N}$ excretion in the faeces and the increased $N$ (and urea) excretion in the urine on treatment 2 (BC) suggest that cooking of barley improved the absorption of carbohydrates in the small intestine leaving less substrates for microbial fermentation and proliferation in the large intestine. This is in good accordance with the AD values of OM and NFE. On the enzyme treatments the average $\mathrm{N}$ intake, absorption and urinary $\mathrm{N}$ were approximately $4 \mathrm{~g}$ / $\mathrm{d}$ less than on treatment 2 , resulting in a relatively better $\mathrm{N}$ utilization, shown as higher BV values.

LAWRENCE (1973 a) did not find any improvement in nitrogen retention, when barley and maize were micronized and fed to pigs. The results from this present trial, however, indicate an increased nitrogen (amino acid) absorption in the small intestine resulting in an improved protein utilization following both cooking and the subsequent enzyme treatment of barley. The decrease in available lysine content of the enzyme treated barleys did not seem to have any adverse effect on protein utilization.

In the small intestine starch is hydrolyzed by a variety of enzymes including e.g. amylases, maltases and glucoamylases, and is degraded into glucose, which can be rapidly absorbed by the mucosa (KIDDER and MANNERS, 1978). The rate of glucose absorption from various sources varies from one carbohydrate to another and from one intake level to another (RERAT, 1985). The first peak of sugars in the portal blood was reached very quickly (45 min.) after glucose and sucrose intake, but later ( 2 hrs.) after intake of maize starch. Large amounts of starch were found in the digestive tract $8 \mathrm{~h}$ after the meal, whereas absorption of glucose and digestion of sucrose was much advanced.

Irrespective of the type of carbohydrate, its degradation in the large intestine leads to the production of acetic, propionic, butyric (VFAs) and lactic acid and small amounts of other organic acids in addition to ethanol, carbon dioxide, methane, hydrogen and small amounts of other gases. The organic acids are readily absorbed and serve the body as an energy source (JusT, 1983). According to Low (1980), VFA may provide $2-3 \%$ of the apparently absorbable energy intake of growing pigs. However, the higher the VFA concentration in faeces, the lower the utilization of ME (JuST, 1983).

Table 6. N-balance, protein utilization and biological value of the diets.

\begin{tabular}{|c|c|c|c|c|c|}
\hline Treatment & 1 & 2 & 3 & 4 & 5 \\
\hline $\mathrm{N}$ intake, $\mathrm{g} / \mathrm{d}$ & 38.3 & 48.0 & 44.1 & 45.4 & 43.0 \\
\hline $\mathrm{N}$ in faeces, $\mathrm{g} / \mathrm{d}$ & 8.0 & 7.4 & 7.6 & 7.8 & 6.8 \\
\hline $\mathrm{N}$ absorbed, $\mathrm{g} / \mathrm{d}$ & 30.4 & 40.7 & 36.5 & 37.6 & 36.1 \\
\hline Apparent dig., $\%$ & 78.0 & 84.6 & 82.9 & 82.4 & 84.1 \\
\hline $\mathrm{N}$ in urine, $\mathrm{g} / \mathrm{d}$ & 15.4 & 18.4 & 13.6 & 15.6 & 15.7 \\
\hline $\mathrm{N}$ retained, $\mathrm{g} / \mathrm{d}$ & 14.9 & 22.3 & 22.9 & 22.0 & 20.4 \\
\hline - $\%$ of intake & 37.2 & 45.8 & 52.8 & 47.8 & 47.4 \\
\hline - of absorbed & 46.9 & 53.9 & 63.8 & 58.0 & 56.4 \\
\hline$-\mathrm{g} / \mathrm{kg} \mathrm{W}^{075}$ & 0.74 & 1.02 & 1.16 & 1.07 & 1.08 \\
\hline BV & 57.1 & 61.8 & 71.2 & 65.8 & 64.0 \\
\hline Urea excreted, g/d & 22.2 & 24.8 & 19.9 & 19.5 & 21.5 \\
\hline$-\mathrm{g} / \mathrm{kg} \mathrm{W}^{075} / \mathrm{d}$ & 1.05 & 1.11 & 0.94 & 0.95 & 1.13 \\
\hline
\end{tabular}


Table 7. Calculated energy values and digestible crude protein.

\begin{tabular}{lccccr}
\hline Raw material & B & BC & BC + A & BC + AG & BC + AC \\
\hline FU/kg DM & 1.09 & 1.17 & 1.10 & 1.11 & 1.12 \\
$\mathrm{Kg} / \mathrm{FU}$ & 1.05 & 0.98 & 1.01 & 1.01 & 0.99 \\
$\mathrm{ME} \mathrm{MJ/kg} \mathrm{DM}$ & 14.27 & 15.32 & 14.45 & 14.53 & 14.75 \\
$\mathrm{NE} \mathrm{MJ/kg} \mathrm{DM}$ & 8.82 & 9.61 & 8.96 & 9.02 & 9.13 \\
$\mathrm{DCP}, \mathrm{g} / \mathrm{kg} \mathrm{DM}$ & 91.5 & 96.7 & 98.2 & 98.8 & 101.2 \\
$\mathrm{DCP}, \mathrm{g} / \mathrm{FU}$ & 83.91 & 82.65 & 89.11 & 89.26 & 90.13 \\
\hline
\end{tabular}

Feeding values of the differently treated barleys were calculated using the digestibility coefficients of the nutrients obtained from the digestibility trial. The results are presented in table 7. Cooked barley had the highest energy value followed by $\mathrm{BC}+\mathrm{AC}, \mathrm{BC}+\mathrm{AG}$, $\mathrm{BC}+\mathrm{A}$ and $\mathrm{B}$, in that order. On ME basis, the energy content of $\mathrm{BC}$ was $7.3 \%$ and that of $\mathrm{BC}+\mathrm{A}, \mathrm{BC}+\mathrm{AG}$ and $\mathrm{BC}+\mathrm{AC} 1.3,1.8$ and $3.4 \%$ higher than that of $\mathrm{B}$, respectively. Digestible crude protein (DCP) content of the enzyme treated barleys was higher than in B and BC. An increased absorption of degraded carbohydrates from the small intestine and the increased nitrogen retention following cooking and enzyme treatment of barley may explain the increased energy values.

\section{Performance trials}

\section{Trial 1}

The chemical composition of the diets is shown in table 8. Different batches of barley and SBM were used for processing and, consequently, the crude protein content of diets 2 and 3 was $0.8 \%$ higher than in diet 1 . Also the sodium chloride content was higher in diets 2 and 3 . The amino acid contents of the diets were similar. Due to a dosage mistake, however, double amounts of L-threonine was added to diet 2, which can be seen as a higher threonine content in that diet.

Piglets on treatment 1 had significantly $(\mathrm{p}<0.05)$ higher live weights at 8 weeks of age and gained significantly $(\mathrm{p}<0.05)$ more

Table 8. Chemical composition of the experimental diets, g/ kg.

\begin{tabular}{|c|c|c|c|c|c|}
\hline \multirow[t]{2}{*}{ Diet } & \multicolumn{3}{|c|}{ Trial 1} & \multicolumn{2}{|c|}{ Trial 2} \\
\hline & 1 & 2 & 3 & 1 & 2 \\
\hline Dry matter & 891 & 893 & 888 & 893 & 892 \\
\hline Crude protein & 183 & 191 & 191 & 175 & 176 \\
\hline Ether extract & 34 & 36 & 39 & 34 & 31 \\
\hline Crude fibre & 34 & 35 & 36 & 32 & 31 \\
\hline Ash & 54 & 64 & 60 & 54 & 52 \\
\hline $\mathrm{N}$-free extracts & 586 & 567 & 562 & 598 & 602 \\
\hline Salt $(\mathrm{NaCl})$ & 5.6 & 10.1 & 8.2 & 5.7 & 5.2 \\
\hline Calsium & 10.3 & 11.2 & 11.1 & 8.7 & 8.2 \\
\hline Phosphorous & 10.0 & 10.0 & 10.2 & 7.2 & 7.6 \\
\hline Lysine & 10.8 & 11.3 & 11.2 & 10.3 & 11.0 \\
\hline Available lysine & 10.1 & 10.7 & 10.5 & - & - \\
\hline Methionine & 4.1 & 4.0 & 4.0 & 3.8 & 3.7 \\
\hline Threonine & 7.5 & 8.8 & 7.8 & 7.3 & 7.4 \\
\hline Tryptophan (cal.) & 2.4 & 2.4 & 2.4 & 2.4 & 2.4 \\
\hline Alfa-amylase, $\mathrm{U} / \mathrm{kg}$ & & & & nd* & 1850 \\
\hline Beta-glucanase, $\mathrm{U} / \mathrm{kg}$ & & & & 2700 & 3750 \\
\hline Protease, U/kg & & & & 5140 & 6000 \\
\hline
\end{tabular}

* not detectable 
Table 9. Piglet performance during the experimental period, mean values.

\begin{tabular}{|c|c|c|c|c|c|}
\hline Treatment & 1 & 2 & 3 & sign. & SEM \\
\hline Piglets & 120 & 139 & 131 & & \\
\hline $\begin{array}{l}\text { Live weight, } \mathrm{kg} / \text { piglet } \\
- \text { at birth } \\
- \text { at } 5 \text { weeks of age } \\
- \text { at } 8 \text { weeks of age }\end{array}$ & $\begin{array}{c}1.58 \\
9.61 \\
19.34^{a}\end{array}$ & $\begin{array}{c}1.53 \\
9.05 \\
18.14^{\mathrm{b}}\end{array}$ & $\begin{array}{c}1.57 \\
9.33 \\
18.39^{b}\end{array}$ & $\begin{array}{c}\text { NS } \\
\text { NS } \\
*\end{array}$ & $\begin{array}{l}0.027 \\
0.181 \\
0.315\end{array}$ \\
\hline $\begin{array}{l}\text { Live weight gain, g/d/piglet } \\
\text { - from birth to } 5 \text { weeks } \\
\text { - from } 5 \text { to } 8 \text { weeks } \\
\text { - from birth to } 8 \text { weeks }\end{array}$ & $\begin{array}{l}230 \\
464^{\mathrm{a}} \\
317\end{array}$ & $\begin{array}{l}215 \\
427^{b} \\
297\end{array}$ & $\begin{array}{l}222 \\
430^{b} \\
300\end{array}$ & $\underset{*}{\mathrm{NS}}$ & $\begin{array}{l}4.85 \\
9.15\end{array}$ \\
\hline $\begin{array}{l}\text { Feed intake, } \mathrm{kg} / \mathrm{piglet} \\
- \text { from birth to } 5 \text { weeks } \\
\text { - from } 5 \text { to } 8 \text { weeks } \\
\text { - from birth to } 8 \text { weeks }\end{array}$ & $\begin{array}{r}0.49 \\
15.88 \\
16.37\end{array}$ & $\begin{array}{r}0.44 \\
14.33 \\
14.77\end{array}$ & $\begin{array}{r}0.63 \\
15.31 \\
15.94\end{array}$ & $\begin{array}{l}\text { NS } \\
\text { NS }\end{array}$ & $\begin{array}{l}0.107 \\
0.708\end{array}$ \\
\hline $\begin{array}{l}\text { Feed conversion, } \mathrm{kg} \text { feed } / \mathrm{kg} \text { gain } \\
- \text { from } 5 \text { to } 8 \text { weeks }\end{array}$ & 1.66 & 1.59 & 1.70 & NS & \\
\hline
\end{tabular}

a b treatment means with different superscripts are significantly different $(p<0.05)$

weight from weaning to the end of the experimental period than piglets on treatment 2 and 3 (table 9). Feed intake was not significantly affected by treatment, but was highest on treatment 3 and lowest on treatment 2 . There were no difference in feed utilization between treatments.

Extrusion of barley decreased DWG and resulted in a higher feed conversion ratio than untreated barley (DANIELSEN, 1986). A decreased availability of amino acids, caused by the heat treatment $\left(140^{\circ} \mathrm{C}\right)$, could explain the inferior performance. In the present trial, however, the amount of available lysine was slightly higher in diets 2 and 3. Steam-cooking (autoclaving, 100 and $120^{\circ} \mathrm{C}$ ), drum drying $\left(120^{\circ} \mathrm{C}\right)$ (DANIELSEN, 1986), steam flaking (Aumaitre, 1976) and micronization (80$140^{\circ} \mathrm{C}$ ) (Danielsen 1986; LaWrence, 1973 a) of barley improved DWG and feed utilization compared with untreated barley. In contrast, extrusion of a barley-wheat mixture (50:50) did not improve piglet performance. Neither did drum drying $\left(115-155^{\circ} \mathrm{C}\right)$ of wheat, rye and barley improve performance of earlyweaned piglets from three to seven weeks of age (DANiElsen, 1986). Performance of pigs between 33 and $80 \mathrm{~kg} \mathrm{LW}$ was not improved by micronization of barley (FERNANDES et al.,
1975). Also flaking of barley resulted in poorer growth rates and feed utilization in bacon pigs (LAWrence, 1972). Again, a decreased availability of amino acids, caused by the heat treatment, could possibly explain the poor performance results.

As was reported above, cooking barley significantly increased the apparent digestibility and energy value. In addition, extrusion of SBM increased the digestibility and improved performance of pigs, although not significantly (NÄsı, 1987). According to these results, an improved piglet performance could be expected when cooked barley and extruded SBM are fed together in the same diet. However, the results from the present trial suggest that the heat processing methods used $\left(\mathrm{T}>130^{\circ} \mathrm{C}\right)$ had a negative effect on the nutritive values of the feeds.

Enzyme supplementation of diet 2 (treatment 3) did not improve piglet performance. If, as could be concluded from these results, cooking and extrusion had a negative effect on the nutritive values of barley and SBM, respectively, enzymes cannot be expected to reverse this effect usually being a result of irreversible reactions (e.g. Maillard). Consequently, the lack of response seems quite logical. 
Table 10. Health status of the piglets during the experimental period, mean values of litters.

\begin{tabular}{|c|c|c|c|c|}
\hline Treatment & 1 & 2 & 3 & signific. \\
\hline Diarrhoea index ${ }^{A}$ & $148^{\mathrm{a}}$ & $284^{b}$ & $304^{b}$ & $* *$ \\
\hline $\begin{array}{l}\text { Mortality, } \% \\
\text { - from start to } 5 \text { weeks } \\
\text { - from } 5 \text { to } 8 \text { weeks } \\
\text { - from start to } 8 \text { weeks }\end{array}$ & $\begin{array}{l}0.83 \\
0.00^{\mathrm{a}} \\
0.83\end{array}$ & $\begin{array}{l}1.44 \\
2.19^{b} \\
3.60\end{array}$ & $\begin{array}{l}1.53 \\
1.55 \\
3.05\end{array}$ & $\begin{array}{c}\text { NS } \\
\text { NS }\end{array}$ \\
\hline Litters with no diarrhoea & 7 & 6 & 4 & \\
\hline Litters medicated due to diarrhoea & - & - & - & \\
\hline
\end{tabular}

a b treatments means with different superscripts are significantly different $\left({ }^{*} \mathrm{p}<0.05,{ }^{* *} \mathrm{p}<0.005\right)$

A scale of severity; 1 =normal faeces, 2 =soft faeces, $3=$ fluid faeces, $4=$ moderate diarrhoea, $5=$ severe diarrhoea index $=$ severity $*$ number of affected piglets * days

Health status of the piglets on treatments 2 and 3 was inferior to that of piglets on treatment 1 (table 10). Diarrhoei index of treatment 3 was on the same level as on treatment 2 , whereas treatment 1 had a markedly lower index $(\mathrm{p}<0.005)$. Mortality percentage on treatment 2 was higher $(\mathrm{p}<0.05)$ than on the other treatments. As mentioned above, the elevated levels of sodium chloride in diets 2 and 3 may have increased the incidence of diarrhoea on those treatments. Aumaitre (1976) reported increased frequency of diarrhoea following steam flaking and popping of barley. This was explained by the slightly higher feed intake from the very first days following weaning. In the present trial, however, feed intake was highest on treatment 1 . Piglets on treatment 2 had the highest mortality both before and after weaning. Seven litters our of twelve on treatment 1 were not affected by diarrhoea. Corresponding figures for treatment 2 and 3 were 6 and 4, respec- tively. None of the litters were medicated due to diarrhoea.

The sodium chloride content of diets 2 and 3 was markedly higher than in diet 1 . It is well known that high intake of salt causes symptoms such as increased water consumption, which can lead to diarrhoea and edema (WRIGHT, 1972). An increased occurrence of diarrhoea was recorded on treatments 2 and 3 (table 10). It is not possible to find out to what extent this was caused by the elevated sodium chloride levels.

\section{Trial 2}

The chemical composition of the diets did not differ exept regarding the lysine content and enzyme activity (table 8 ). The lysine content of diet 2 was slightly higher than in diet 1. The results from the enzyme activity analysis indicate high levels of natural activity, especially of beta-glucanase and protease.

Table 11. Performance during the experimental period, mean values per piglet.

\begin{tabular}{lccccc}
\hline Treatment & 1 & sd & 2 & sd & sign. \\
\hline Piglets & 24 & & 24 & 1.3 & NS \\
Initial weight, kg & 13.2 & 1.3 & 13.4 & 2.4 & NS \\
Final weight, kg & 23.5 & 3.0 & 24.5 & 1.8 & NS \\
Weight gain, kg & 10.3 & 2.6 & 11.1 & 586 & NS \\
Daily weight gain, g & 542 & 135 & 19.0 & 1.4 & NS \\
Feed intake, kg & 18.8 & 1.0 & 1.70 & 0.04 & \\
Feed/gain, kg/kg & 1.83 & 0.13 & & & \\
\hline
\end{tabular}

$\mathrm{NS}=$ not significant 
Piglets on treatment 2 had higher live weights at the end of the trial, gained more weight and consumed more feed than piglets on treatment 1. Feed utilization was improved on treatment 2. Due to considerable variation within the treatments, none of the performance parameters was significantly different between treatments.

The marked improvement of performance by the higher inclusion level of enzyme activities indicate that the digestive capasity of young pigs can be enhanced by enzyme supplementation of the diet. Enzyme pre-treatment of barley, using a mixture of carbohydrate, starch and protein degrading enzymes, markedly decreased the incidence and severity of post-weaning diarrhoea (INBORR and Ogle, 1988). Тномке et al. (1980) reported improved performance of piglets when fed high viscosity barley supplemented with betaglucanase. Accordingly, Collier and HARDY (1986) and Newman (1983) reported improved performance of pigs following enzyme supplementation of barley-SBM based diets.

\section{Conclusions}

Cooking of barley significantly improved the digestibility of barley. A subsequent en- zyme treatment of the cooked barley decreased the digestibility to the same level as before cooking. This may have been a consequence of the browning reactions between reducing sugars and lysine resulting in poorly digestible complexes. This was indicated by the markedly elevated concentrations of glucose and the decreased amounts of available lysine in the enzyme treated barleys.

The results from the $\mathrm{N}$ balance measurements indicate a change in the availability of the energy following the treatments of barley. All treatments seemed to improve the energy uptake from the small intestine, but the enzyme treatments resulted in a relatively better $\mathrm{N}$ utilization than cooking.

In the piglet performance trials enzyme supplementation of the diets did not give any conclusive results. In trial 1 , the lack of response was probably a consequence of the inclusion of heat damaged raw materials (cooked barley and extruded SBM, $\mathrm{T}>130^{\circ} \mathrm{C}$ ), resulting in impaired performance. In trial 2 , an increased enzyme activity inclusion rate in a diet containing hydrothermally treated barley and SBM $\left(\mathrm{T}<60^{\circ} \mathrm{C}\right)$ resulted in improved performance, suggesting that more gentle heat processing methods would be preferable in order to leave more potential for supplemental feed enzymes.

\section{References}

Aumaitre, A. 1976. Evaluation de divers traitments technologiques des cereals. IV. Influence du floconnage et de l'expansion de l'orge et du mais sur les performances du porcelet serve a 21 jours: effets sur la digestibilite des elements de la ration. Ann. Zootech., 25: 41-51.

BıornhaG, G. \& Jonsson, E. 1983. Replacable gastrointestinal cannulas for small ruminants and pigs. Livest. Prod. Sci. 11: 179-184.

Collier, B. \& Hardy, B. 1986. The use of enzymes in pig and poultry feeds. Feed Compounder $6(4): 28-30$.

DANIELSEN, V. 1986. Varmebehandlet korn till smågrise. Hyologisk Tidskrift No. 11, pp. 50-51.

Fernandes, T.H., Hutton, K. \& Smith, W.C. 1975. A note on the use of micronized barley for growing pigs. Anim. Prod., 20: 307-310.
Graham, H., Hesselman, K., Jonsson, E. \& Ảman, P. 1986. Influence of beta-glucanase supplementation on digestion of a barley-based diet in the pig gastrointestinal tract. Nutr. Rep. Int., Vol. 34, No. 6: 1089-1096.

Goering, H.R. \& VAn Soest, P.J. 1970. Forage fibre analysis. Agricultural Handbook No. 379. United States Dept. of Agric. Washington.

Hesselman, K. 1983. Ph. D. thesis. Swedish Univ. of Agric. Sci. Cited in Hesselman, K and Ảman, P. 1985. A note on microscopy studies on water and betsglucanase treated barley. Swedish J. agric. Res. 15: 139-143.

Huisman, J. \& Poel, A.B.F., Van Der. 1987. Effects on antinutritional factors (ANF) in pig nutrition. 38th annual meeting of the EAAP., Lissabon, Portugal. 
Manuscript, pp. 14.

Hurrell, R.F. \& Carpenter, K.J. 1981. The estimation of available lysine in foodstuffs after Maillard reactions. Prog. Fd. Nutr. Sci. Vol. 5. pp 159-176.

Inborr, J. \& OGle, R.B. 1988. Effect of enzyme treatment of piglet feeds on performance and post weaning diarrhoea. Manuscript. Submitted for publication.

Just, A. 1982. The net energy value of crude (catabolized) protein for growth in pigs. Livest. Prod. Sci., 9: 349-360.

-1983 . The role of the large intestine in the digestion of nutrients and amino acid utilization in monogastrics. IV Int. Symp. on Protein metabolism and nutrition. Ed. INRA, Publ. I (les Colloques de I'INRA, No. 16).

Kidder, D.E. \& Manners, M.J. 1978. Digestion in the pig. Bath (UK). pp. 201.

Krogdahl, A. 1987. Dietary fibres are trouble makers. Poultry international, april '87, p. 20-24.

KNEALE, W.A. 1972. Effect of heat on the feeding value of barley in rations for bacon pigs. Exp. Husb. 21: 69-77.

Lawrence, T.L.J. 1972. High level cereal diets for the growing/finishing pig. VI. An evaluation of flaked maize, wheat and barley when included at high levels in the diet of the weaned pig grown to cutter weight (160 lb). J. Agric. Sci., Camb., 79: 155-160.

- 1973 a. An evaluation of the micronization process for preparing cereals for the growing pig. 1. Effects on digestibility and nitrogen retention. Anim. Prod. 16: 99-107.

- 1973 b. An evaluation of the micronization process for preparing cereals for the growing pig. 2. Effects on growth rate, food conversion efficiency and carcass characteristics. Anim. Prod. 16: 109-116.

Low, A.G. 1980. Nutrient absorption in pigs. J. Sci. Food Agric., 31, 1087-1130.

Markström, B., Pettersson, D. \& Hesselman, K. 1985. Betaglukanas tillsats till grov- och finmalet korn - ett smältbarhetsförsök med smågrisar. Sveriges Lantbruksuniversitet, Inst. för husdjurens utfodring och vård. Rapport 149.

Matsubara, H., Hagihara, B., Nakal, M., Komakı, T., Yonetani, T. \& Okunukı, K. 1958. J. Biochem., Vol. 45: $251-258$.

Miller, G.L. 1959. Anal. Chem. 31, 426-428.

Newman, C.W., Eslick, R.F., Pepper, J.W. \& El-negouMY, A.M. 1983. Performance of pigs fed hulless and covered barleys supplemented with or without a bacterial diastase. Nutr. Rep. Int., Vol. 22, No 6: 833837.
Noland, P.E., Campbell, D.R., Gage, Jr., R.K., Sharp, R.N. \& Johnson, Z.B. 1976. Evaluation of processed soybeans and grains in diets for young pigs. J. Anim. Sci. 48: 763-769.

NĀsı, M. 1984. Trämelass som svinfoder. NJF seminar No. 57, 16:1, Stenhamra, Sweden.

-1987 . The feeding value of differently treated soybean meals for pigs. Unpublished.

Pao, S.R., Carter, F.L. \& Frampton, V.L. 1963. Anal. Chem. 35, 1927-1930.

Papasolomontos, S.A. \& Wilkinson, J.I.D. 1976. In Optimizing the utilization of cereal energy by cattle and pigs, p. 31. London; US Feed Grains Council. (Cited in Recent advances in animal nutrition, 1978. Eds. Haresign, W and Lewis D. Publ. Butterworths, London.)

RerAT, A.A. 1985. Intestinal absorption of end products from digestion of carbohydrates and proteins in the pig. Arch. Tierernähr., 35; 7: 461-480.

Salo, M-L., TuORI, M. \& KiISKinen, T. 1982. Rehutaulukot ja ruokintanormit. 70 p. Helsinki.

Soest, P.J. VAn. 1982. Nutritional ecology of the ruminant. O\&B Book Inc., Corvallis, OR.

Thacker, P.A., Campbell, G.L. \& Grootwassink, J.W.D. 1988. The effect of beta-glucanase supplementation on the performance of pigs fed hulles barley. Unpublished. Manuscript, pp. 8.

Thomke, S., Rundgren, M \& Hesselman, K. 1980. The effect of feeding high-viscosity barley to pigs. 31st annual meeting of the European Association of Animal Production, Munich, FRG. Commission on animal nutrition. Stencil, pp. 5.

Weltzien, E.M. \& Aherne, F.X. 1986. The effect of anaerobic storage and processing of high moisture barley on its amino acid and beta-glucan digestibility by growing swine. Can. J. Anim. Sci., Vol. 66: 11861187.

WrIGHT, D.L. 1972. Sodium salt poisoning in swine. Southwest Vet. 25 (4): 319-320.

Zebrowska, T. 1973. Digestion and absorption of nitrogenous compounds in the large intestine of pigs. Roczn. Nauk. Roln. 95B: 85.

ÅmAN, P. 1987. Analys och kemisk sammansăttning av svensk spannmål. Fakta - husdjur, nr 3. Sveriges Lantbruksuniversitet.

- \& Hesselman, K. 1984. Analysis of starch and other main constituents of cereal grains. Swedish J. Agric. Res. 14: 135-139.

Ms received 


\section{Entsyymikäsittelyn vaikutus esikypsennetyn ohran sulavuuteen sekä entsyymilisäyksen vaikutus porsasrehun tuotantovaikutukseen}

\author{
J. Inborr, ${ }^{1}$ M. Näsi ${ }^{2}$ and K. Suomi ${ }^{3}$
}

\author{
' Suomen Sokeri Oy, Finnfeeds Ltd \\ Forum House, Brighton Road, \\ Redhill, Surrey RHI 6YS, England \\ ${ }^{2}$ Helsingin Yliopisto, \\ kotielaintieteen laitos, \\ Viikki, $07100 \mathrm{Helsinki}$ \\ ${ }^{3}$ Maatalouden tutkimuskeskus, \\ Sikatalouden tutkimusasema \\ 05840 Hyvinkää
}

Kasvavilla sioilla tehdyssă sulavuuskokeessa tutkittiin esikypsennyksen ja esikypsennyksen jälkeen suoritetun entsyymikäsittelyn vaikutusta ohran sulavuuteen ja valkuaisen hyvăksikăyttőon. Kahdessa porsaskokeessa tutkittiin ohran ja soijarouheen lämpökäsittelyn sekä rehuun lisătyn entsyymiseoksen vaikutusta kasvuun, rehun hyvăksikăyttoooon ja ripulin esiintymiseen.

Sulavuuskokeessa oli viisi sikaa, joiden keskimaaăräinen elopaino kokeen alkaessa oli $40 \mathrm{~kg}$. Koe toteutettiin $5 \times 5$ latinalaisena neliönă ja jaksojen pituus 12 päivăå.

Esikypsennys paransi merkitsevăsti jauhetun ohran kokonaissulavuutta ja energia-arvoa. Esikypsennetyn ohran entsyymikäsittely alensi sulavuutta jauhetun ohran tasolle. Esikypsennys paransi typen hyvăksikäyttőă ja biologista arvoa (BV). Entsyymikăsittelyn vaikutus typen hyvăksikäyttooon ja biologiseen arvoon oli suurempi kuin esikypsennyksen.

Esikypsennetyn ohran rehuarvo oli 1,17 ry/kg k.a. (15,32 MJ ME/kg k.a.) ja jauhetun ohran 1.09 ry/kg k.a.
(14,27 MJ ME/kg k.a.). Entsyymikăsiteltyjen ohrien rehuarvot olivat esikypsennetyn ohran ja jauhetun ohran vălillä.

Ensimmäisessă porsaiden kasvatuskokeessa 36 pahnuetta jaettiin kolmeen ryhmäăn. Koerehut olivat vapaasti saatavilla toisesta viikosta syntymăn jălkeen kahdeksanteen elinviikkoon asti. Porsaat vieroitettiin viiden viikon iässả. Kontrollirehussa (ryhmä 1) oli jauhettua ohraa ja soijarouhetta. Toisessa koerehussa (ryhmä 2) oli esikypsennettyä ohraa ja ekstrudoitua soijarouhetta. Kolmas koeryhmä sai toisen koeryhmän rehua, johon oli lisătty entsyymiseos (ryhmä 3).

Ryhmien 2 ja 3 porsaiden keskimääräinen loppupaino ja painonlisăys olivat merkitsevăsti $(\mathrm{p}<0,05)$ pienemmăt kuin kontrolliryhmăn. Rehujen syöntimäärissă ja hyvăksikäytőssä ei ryhmien välillă ollut eroja. Ripulia esiintyi koeryhmässä merkitsevästi enemmän kuin kontrolliryhmãssã.

Toisessa kasvatuskokeessa 48 vastavieroitettua porsasta jaettiin kahteen ryhmäăn. Kummankin ryhmän porsaat jaettiin neljảän kuuden porsaan ryhmảăn. Rehut olivat vapaasti saatavilla koko 19 päivăn koejakson ajan. Rehujen koostumus oli sama, mutta koerehuun (ryhmä 2) entsyymiseoksen lisäystaso oli viisinkertainen $(0,5 \%)$ verrattuna kontrollirehuun $(0,1 \%)$.

Koeryhmän lisảkasvu oli $8 \%$ ja rehun hyväksikäyttő $7 \%$ parempi kuin kontrolliryhmän. Erot eivăt olleet merkitseviä $(\mathrm{p}<0,05)$. Terveydentilassa ei ollut eroa ryhmien välillă. 